Research Article

\title{
The Effect of Flipped-Problem Based Learning Model Integrated with LMS-Google Classroom for Senior High School Students
}

\author{
Rahmi RAMADHANI ${ }^{1}$, Rofiqul UMAM ${ }^{2}$, Abdurrahman \\ ABDURRAHMAN $^{3}$, and Muhamad SYAZALI ${ }^{4}$
}

Received: 2 April 2019 Accepted: 11 June 2019

\begin{abstract}
The purpose of this study was to determine the effect of using the LMS-Google Classroom-based Flipped-Problem Based Learning Model (FPBLM) in the process of learning mathematics in high schools in Medan, North Sumatra, Indonesia. In this study also saw the interaction between the level of Prior Mathematics Ability (PMA) of students with the application of flipped-problem based learning models based on LMS-Google Classroom. PMA students consist of high, medium and low levels This research is quasi-experiment research with pre-test post-test control group design. The sample in this study was the second level high school students from two schools totaling 62 people. Two-way ANOVA Test and Post Hoc-LSD Test was used. Based on the analysis test, it was found that the average mathematics learning outcomes of students taught using the FPBLM based on Google Classroom LMS experienced a significant increase compared to conventional learning. The results of the questionnaire in learning also obtained results that students at the second level of high school felt enthusiastic, motivated and eager to take part in learning in the classroom. Digital-based learning with the model of FPBLM on LMS-Google Classroom provides a new experience for second-level students in High School in participating in mathematics learning both in class and outside the classroom.
\end{abstract}

\section{Keywords}

flipped-problem based learning, blended learning, LMS-Google Classroom, mathematics learning

\section{To cite this article:}

Ramadhani, R., Umam, R., Abdurrahman, A., \& Syazali. M. (2019).The Effect of Flipped-Problem Based Learning Model Integrated with LMS-Google Classroom For Senior High School Students. Journal for the Education of Gifted Young Scientists, 7(2), 137-158. DOI: http://dx.doi.org/10.17478/jegys.548350

${ }^{1}$ Faculty of Engineering and Computer Science, Universitas Potensi Utama, Indonesia. rahmiramadhani3@gmail.com ${ }^{2}$ School of Science and Technology, Kwansei Gakuin University, Japan. egk71822@kwansei.ac.jp

${ }^{3}$ Department of Science Education, Faculty of Teacher Training and Education, University of Lampung, Bandar Lampung, Lampung Province, Indonesia. abdurrahman.1968@ffkip.unila.ac.id

${ }^{4}$ Mathematics Education Department, Faculty of Education and Teacher Training, Universitas Islam Negeri Raden Intan,

Lampung, Indonesia. muhamadsyazali@radenintan.ac.id 


\section{Introduction}

Education 4.0 is one part of the development of the 4.0 Industrial Revolution in Indonesia. The impact of the development of 4.0 education is the development of technology-based education (Abdurrahman, Saregar \& Umam, 2018). Technology makes transformed education more dynamic both in terms of learning and teaching. Technology not only has an effect on the relationship between teachers and students, but also provides an increase in the value of the system from the learning process itself (Abdurrahman, Nurulsari, Maulina, \& Ariyani, 2019). The use of technology in the world of education has an influence on improving the learning process, making the learning process more efficient and effective, and providing knowledge, skills to new experiences for both teachers and students in carrying out learning(Muhamad Syazali et al., 2019). This has become a new breakthrough in the world of education, where technology is not only as a medium, but also used in systems, methods to learning techniques that increase the level of education in a higher direction (Maskur, Syazali, \& Utami, 2019), in accordance with the educational objectives 4.0 in the Industrial Revolution (Ghavifekr\& Rosdy, 2015; Shah, 2013; Torii \& Carmen, 2013). Technology development in the world of education is divided into two things, the first is the development of technology used to increase the skills of teachers and education staff in using technology in the learning process (Abdurrahman, Cris Ayu Setiyaningsih, 2019), and secondly, technology development is integrated into learning activities, ranging from curriculum, systems, models to methods learning that aims to increase the effectiveness of learning (Syahrir et al., 2019), both in the classroom and outside the classroom. Through the use of technology in the world of education, it is expected to increase both in terms of the skills of teachers and students, to the effectiveness of increasingly widespread learning. (Dočekal \& Tulinská, 2015; Lestari et al., 2019; Murati \& Ceka, 2017; Ramadhani \& Narpila, 2018). The use of technology in the learning process provides space for teachers to not only provide learning in the classroom, but also can be continued outside the classroom through technological assistance. Through digital-based learning, technology provides an important role in delivering students to understand the subject matter (M. Syazali et al., 2019). Digital-based learning and technology also provide more opportunities for teachers to create learning, ranging from teaching materials, to evaluating learning outcomes that provide new experiences for students in learning mathematics (Borba et al., 2016; Eady \& Lockyer, 2013; Lavicza, 2010).

Based on the explanation above, one of the learning models that can be integrated with technology is the Blended Learning model. The blended learning model is a learning model that combines face-to-face learning with technology and digital learning (e-learning). The blended learning model supports the learning process with a mixture of various learning activities such as face to face, media use, and digital internet based learning (Rufaidah, AtIrsyadi, Saregar, \& Umam, 2018). This gives 
students the opportunity to experience an efficient learning environment and includes spectacular aspects of learning such as online and traditional learning platforms, media for delivering learning content, flexible learning models, and independent learning activities. The main focus is to provide an interesting and motivating learning environment that can increase the effectiveness of their learning. (Chin et al., 2018; Harahap \& Manurung, 2019; Tsai, Lin, \& Lin, 2017). The blended learning model has several types, including Station Rotation, Lab Rotation, Individual Rotation, Flipped Classroom, Flec, A La Carte, and Virtual Enriched (Lopes \& Soares, 2018; Staker \& Horn, 2012). The types of blended learning models can be seen in Figure 1 below:

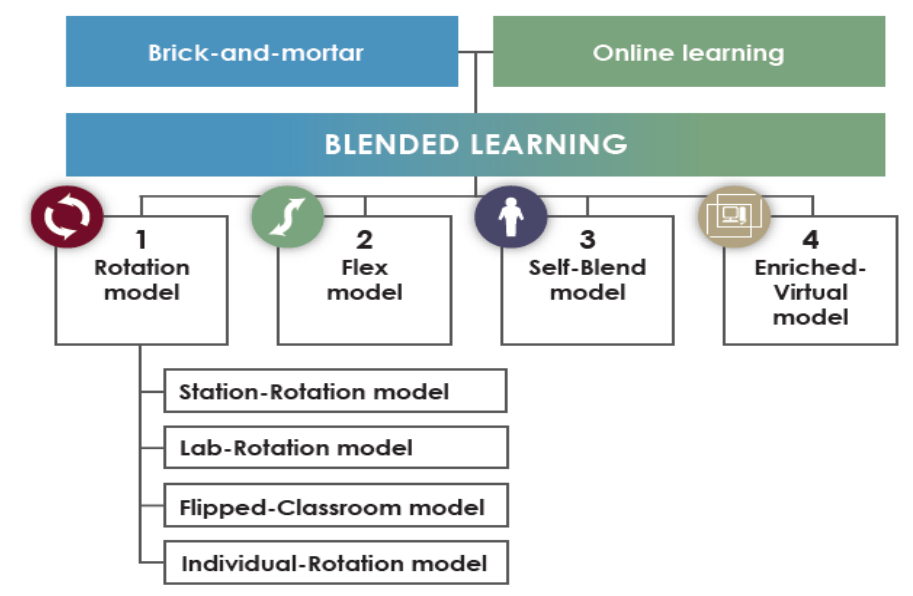

\section{Figure 1}

Types of Blended Learning Models (Staker \& Horn, 2012)

In this study, researchers chose to use the flipped-classroom model. The flippedclassroom model is a mixed learning model in which learning activities are carried out in two stages, namely classroom learning and learning outside the classroom. In the first phase, the learning phase in the classroom is conducted through discussion activities, prioritizing students' low cognitive abilities as the main focus for improvement and making learning activities more active, interactive and meaningful. While learning outside the classroom is done using an online platform containing learning material and learning videos that provide opportunities for students to study material before the material is taught, and develop students' ability to learn independently (Çevikbaş\& Argün, 2017; O’flaherty \& Phillips, 2015). In the learning phase outside the classroom, researchers use online platforms or also called Learning Management Systems (LMS). LMS consists of several types, namely Moodle, Schoology, Google Classroom, Edmodo, Quipper School, Chamilo, and Khan Academy. Researchers in this case choose LMS with the type of Google Classroom. 
Google Classroom is one of the products from Google which was launched in 2014 through Google Apps for Education (GAFE). The Google Classroom application has advantages, including free to use, easy to use for both teachers and students because of the appearance and use of social media (Facebook, Twitter), and integrated with other Google applications, such as Google Form, Google Drive, Google Doc, Google Slides, You Tube, and others (Abid Azhar \& Iqbal, 2018; Rohman, 2017).

The implementation of flipped-problem based learning models used in research, both in the first phase (learning in the classroom) and in the second phase (learning outside the classroom) refers to the syntax of problem-based learning models. The steps of learning activities refer to problem-based learning including orientation, organization, investigation, percentage and analysis and evaluation( $\mathrm{Hu}, \mathrm{Xing}, \& \mathrm{Tu}$, 2018). The description of the steps in using the flipped-problem based learning model in detail can be seen in Table 1 below:

\section{Table 1}

Syntax Model Flipped-Problem Based Learning

\begin{tabular}{|c|c|c|}
\hline Steps & Procedures & Student Activities \\
\hline Step 1 & $\begin{array}{l}\text { Problem } \\
\text { Oriented }\end{array}$ & $\begin{array}{l}\text { Students understand the details of the issues to be discussed. } \\
\text { Problems are taken from the teaching material being studied. } \\
\text { Students analyze and find out how to solve problems. }\end{array}$ \\
\hline Step 2 & $\begin{array}{l}\text { Organized } \\
\text { Students }\end{array}$ & $\begin{array}{l}\text { Students can solve problems by finding out problems that are } \\
\text { similar or similar to the problems being analyzed. At this } \\
\text { stage, students can group the details of the issues discussed. }\end{array}$ \\
\hline Step 3 & $\begin{array}{l}\text { Investigations } \\
\text { Guide as } \\
\text { Individual or } \\
\text { Group }\end{array}$ & $\begin{array}{l}\text { After students classify the details of the problem to be } \\
\text { discussed, students can investigate the problem individually } \\
\text { or in groups. }\end{array}$ \\
\hline Step 4 & $\begin{array}{l}\text { Attainments } \\
\text { Development } \\
\quad \text { and } \\
\text { Presentations }\end{array}$ & $\begin{array}{l}\text { Students can develop and present the results of discussion of } \\
\text { the problems being discussed. At this stage, students can } \\
\text { compare steps to resolve other problems and find out the } \\
\text { steps to solve the most appropriate problems. }\end{array}$ \\
\hline Step 5 & $\begin{array}{l}\text { Problem } \\
\text { Solving } \\
\text { Analysation } \\
\text { and Evaluation }\end{array}$ & $\begin{array}{l}\text { Students can conduct analysis to reflect and evaluate the } \\
\text { results of investigations regarding solving problems that are } \\
\text { being discussed. Students can conclude the correct and } \\
\text { appropriate problem solving. }\end{array}$ \\
\hline
\end{tabular}

The use of the above syntax in applying the flipped-problem based learning model can also be seen in Figure 2 below: 


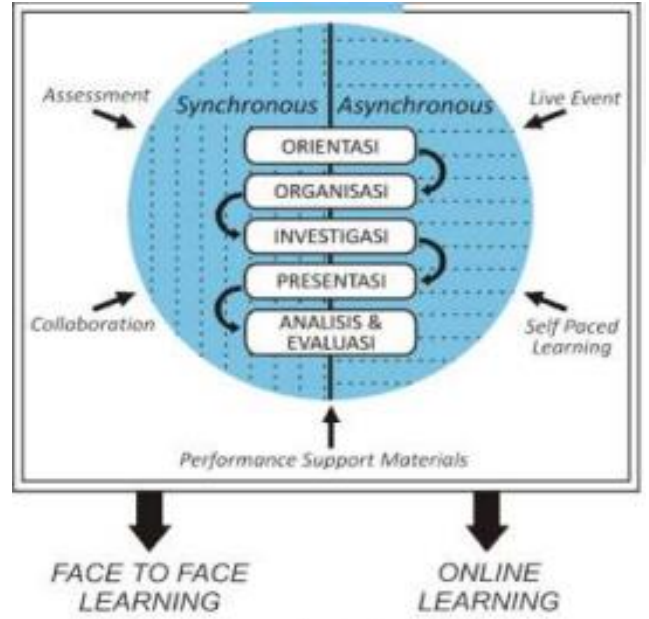

\section{Figure 2}

\section{Implementation of the Flipped-Problem Based Learning Model}

The key to success in using the flipped-problem based learning model is to encourage students to be more active in applying new information to various contexts in a creative way (Capone, De Caterina, \& Mazza, 2017). Referring to the opinion of Capone, et al., The application of mathematical problems in learning using the flipped-problem based learning model is very emphasized, in addition to improving students' mathematical abilities through learning outcomes, but also can improve students' ability to solve problems, especially internal problems in everyday life. In accordance with Table 1 above, the use of the problem-based learning model syntax as the basis of learning syntax used in both the first and second phases of learning using the flipped-problem based learning model. The following learning activities are used in the flipped-problem based learning model:
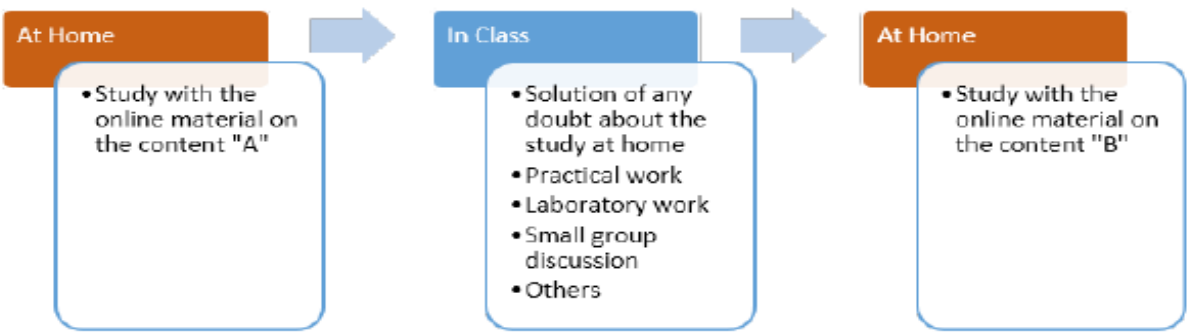

\section{Figure 3}

Sequence of Learning Activities Using the Flipped-Problem Based Learning Model (Andrade \& Coutinho, 2016)

Based on Figure 3 above, the use of the flipped-problem-based learning model is expected not only to replace the teacher's role as a learning video for activities in the 
second learning phase, but can emphasize students' skills and independence in using technology, and find solutions to problems encountered in the learning phase first (Ozdamli\& Asiksoy, 2016). The effectiveness of the learning process in the second phase can be arranged and controlled by the teacher with online discussions held. The application of learning using the blended learning model, especially in the type of flipped classroom provides significant results in improving student learning outcomes, both in mathematics learning, and learning in other fields. The results of the study state that the application of the flipped classroom model provides new experiences for students, especially in the second learning phase. Students feel enthusiastic when participating in digital classes by looking at learning videos and students feel given responsibility when studying teaching material before being studied through a short video provided by the teacher in the digital class. Learning to use the flipped classroom model also helps students to understand the teaching material that has been obtained in the first learning phase when studying the teaching material in the second learning phase (D'addato\& Miller, 2016; Gladys Ann O. Malto, Dalida, \& Lagunzad, 2018; Larsen, 2015; Loch, Borland, \& Sukhorukova, 2016; Scholarsarchive \& Young, 2014; Strohmyer, 2016).

Referring to the explanation above, the application of technology in the learning process can be done using the model of Flipped-Problem Based Learning based on LMS-Google Classroom which provides new experiences for students to learn teaching material, to develop student skills both in terms of learning and in terms of technology use. Researchers are interested in applying the model and see the effects of its application in student learning outcomes, especially in mathematics learning for second-level high school students in Medan, North Sumatra.

The research step in the experiment and control class can be described as:

- In research in the control class, the teacher uses a conventional learning model by providing direct learning through lecture techniques. Students are required to focus on the direction given by the teacher. The purpose of conventional learning methods is to help students develop the ability to understand and explore their own knowledge, but still need direction from the teacher in an effort to help students deal with problems that are difficult to solve during the learning process in the classroom. The teacher invites each student to solve problems and ask questions if they have difficulties. During the learning process, each student can write various information obtained from the teacher. All information obtained is useful for solving problems given by the teacher. Conventional learning creates passive learning, because learning interactions only occur in one direction. However, through conventional learning, the learning conditions are expected to be more conducive and calm, because students only focus on 
what is taught by the teacher in front of the class, without having to interact with other students.

- In the research in the experimental class, the teacher used a flipped-problem based learning model based on the LMS-Google Classroom. In this study, the teacher plays an active role as a facilitator. Learning is done in two stages, namely learning in the classroom and learning outside the classroom. Inclass learning is done with discussions about the material to be learned. The teacher gives a problem that will be solved and discussed in groups. Learning is focused on the problems encountered in teaching material. Students discuss each other to find solutions to the problems given. After learning in the classroom is done, the learning process enters the second stage, namely learning outside the classroom. Learning outside the classroom is done with the help of Google Classroom as an outside classroom learning management system. Teachers create digital classes with Google products, create learning content ranging from teaching materials in the form of videos, power point slides, modules to creating assessment content. During the second phase, students will be given access to enter the digital class that has been made by the teacher, then learn the teaching material posted by the teacher. Students can also hold discussions in the digital classroom veranda space. The teacher has full access to giving announcements and posting material to the discussion schedule and daily assessment schedule to the final assessment. During the learning process in the second phase, students can discuss whenever and wherever. After the learning process in the second phase is complete, the teacher will give a final evaluation. Learning in the second phase expects students to develop independent and creative learning abilities. Learning using flipped-problem based learning models based on LMS-Google Classroom provides new experiences for students and teachers. Students are more active and creative in the learning process, and students' ability to use technology is increasing.

\section{Method}

\section{Research design}

This study uses quasi-experimental research with the design of the pre-post-test test control group design. In accordance with the objectives of the research, aims to see the effect of using flipped-problem based learning models based on LMS-Google Classroom in mathematics learning. This study takes 12 weeks with four hours of face-to-face meetings per week (48 hours for the whole). In the experimental class and the control class using the same teaching material and teachers, the researchers in this article. The teacher has no relationship with the students or the school where the research was conducted, so that this study provides objective results. 


\section{Participants}

Participants in this study were second-level students in high schools in Medan, North Sumatra, Indonesia. Participants in this study used two different schools as learning classes selected through purposive sampling method. The number of participants in this study were 62 students. 33 students in the experimental class will be taught using the flipped-problem-based learning model based on LMS-Google Classroom and 29 students in the control class will be taught using conventional learning. Participants in this study were second-year students in senior high schools, who have an age range of 15-17 years. The selection of students in that range was due to the fact that at these age range students were at the formal operating level (11 years and above) according to the cognitive development theory developed by Piaget. In the formal operating period, students are at the peak level of development of cognitive structures, in which students are able to think logically for all types of hypothetical problems, verbal problems, and he can use scientific reasoning and be able to accept other people's views (Heidari\& Rajabi, 2017; Lefa, 2014). In this study also saw the interaction between the level of PMA of students with the application of flippedproblem based learning models based on LMS-Google Classroom. PMA students consist of high, medium and low levels. Students who are in the category of high PMA as many as 13 people, students who are in the category of moderate PMA as many as 34 people and students who are in the category of low PMA as many as 15 people. Students' PMA scores are taken from the results of students' mathematics exams in the last semester (odd semester). This research was conducted from January to May 2018, namely in the even semester of 2017-2018 learning year at Medan YPK High School and Medan 6 Public High School.

\section{Data Collection}

Data obtained from the results of the final evaluation on each learning class (experimental class and control class). Tests given are essay tests which number five questions and are related to Statistics material. In addition to the test assessment, data from the research results were also collected through questionnaires on the implementation of flipped-problem based learning models with the LMS-Google Classroom.

\section{Data Analysis}

Data were analyzed using descriptive statistical tests (mean and standard deviation), and using inferential two-way ANOVA statistical tests and Post Hoc-LSD tests to see how much influence the learning model had on students' mathematics learning outcomes, and to see how much PMA interaction with results learning and the different interactions between PMA students. The results of the study were analyzed using the SPSS 25.0 statistical tool with statistical significance values of 0.05 level 
with two tails tests. For testing homogeneity of data used the Kolmogorov-Smirnov Test and for testing the normality of the data used the Levene's Testof Quality test.

\section{Results and Discussion}

After calculating students' mathematics learning outcomes it was found that the average learning outcomes of students in experimental class (taught with the flippedproblem based learning model with the LMS-Google Classroom) was higher than students in control class (taught with conventional model). Another result was found that the increasing of students' mathematics learning outcomes in experiment class didn't influence with students' PMA. That was interpretable mean implementation of flipped-problem based learning model with the LMS-Google Classroom gave significant impact for students' mathematics learning outcomes. The same result was found that students' PMA didn't give contribution for increasing students' mathematics learning outcomes (Akkoyunlu \& Soylu, 2008; Maya \& Sumarmo, 2011).

The average mathematics learning outcomes of students taught using the flippedproblem based learning model with the LMS-Google Classroom (experimental class) are higher than the average learning outcomes of students taught using conventional models (control class). This can be seen in Table 2 below:

Table 2

Descriptions of Student Learning Outcomes in Experimental Classes and Control Classes

\begin{tabular}{lcccccc}
\hline \multicolumn{7}{c}{ Descriptive Statistics } \\
\hline & N & Minimum & Maximum & Mean & $\begin{array}{c}\text { Std. } \\
\text { Deviation }\end{array}$ & Variance \\
\hline Pre_Test_Experiment & 33 & 45.00 & 80.00 & 59.2727 & 8.82211 & 77.830 \\
Post_Test_Experiment & 33 & 65.00 & 90.00 & 77.0000 & 5.32682 & 28.375 \\
Pre_Test_Control & 29 & 50.00 & 75.00 & 64.5862 & 7.23838 & 52.394 \\
Post_Test_Control & 29 & 65.00 & 85.00 & 76.4483 & 4.64901 & 21.613 \\
\hline
\end{tabular}

Based on Table 2 above, it can be seen that the average pre-test student scores in the experimental class are lower (59.27) than the average pre-test scores of students in the control class (64.59). But different things can be seen in the average post-test scores of students in the experimental class higher (77.00) than the average post-test scores of students in the control class (76.45). Improving student learning outcomes in Statistics teaching materials in the experimental class results in a higher increase than the increase in mathematics learning outcomes of students in the control class. Increased learning outcomes can be determined from the difference between students' post-test scores and student pre-test scores divided by the difference in value total totals with student pre-test scores. The result of the increase is also called the normalized N-Gain(Hake, 1999). Improving student learning outcomes both in 
the experimental class and in the control class can be seen in Table 3 and Table 4 below:

\section{Table 3}

N-Gain Mathematics Learning Outcomes in the Expert Class and Control Class

\begin{tabular}{ccccccc}
\hline \multicolumn{7}{c}{ Descriptive Statistics } \\
\hline & N & Minimum & Maximum & Mean & Deviation & Variance \\
\hline NGain_Experiment_Class & 33 & .22 & .60 & .4303 & .09635 & .009 \\
NGain_Control_Class & 29 & .17 & .45 & .3269 & .09138 & .008 \\
\hline
\end{tabular}

\section{Table 4}

N-Gain Mathematics Learning Outcomes Based on PMA Values

\begin{tabular}{lcccccc}
\hline \multicolumn{7}{c}{ Descriptive Statistics } \\
\hline \multirow{2}{*}{ NGain_Experiment_Class } & PMA & N & Minimum & Maximum & Mean & Std. Deviation \\
& High & 7 & .37 & .60 & .48 & .088 \\
& Middle & 20 & .22 & .60 & .42 & .106 \\
& Low & 6 & .33 & .47 & .40 & .052 \\
NGain_Control_Class & High & 6 & .30 & .45 & .40 & .066 \\
& Middle & 14 & .20 & .45 & .33 & .091 \\
& Low & 9 & .17 & .41 & .27 & .076 \\
\hline
\end{tabular}

Based on Table 3 above, it can be seen that, the increase in mathematics learning outcomes of students in the experimental class obtained an average N-Gain value of 0.43 (medium category), while the increase in mathematics learning outcomes of students in the control class obtained an average $\mathrm{N}$-Gain of 0.33 (medium category). Both the results of the average N-Gain of students both in the experimental class and in the control class are not too much different and are equally included in the category of $\mathrm{N}$-Gain being. Likewise, if you see the difference in the standard deviation values in the two learning classes differ significantly, so it can be concluded that each of the data studied spreads thoroughly and has a tendency towards differences with each other. So, the two data used can be said to be heterogeneous(Salkind, 2007).

In Table 4 above, information is also provided about the value of the NGain of students' mathematics learning outcomes in each category of PMA values (high, medium and low) for each learning class. The average NGain value for high category PMA in the experimental class (0.48) is higher than the control class (0.40). Likewise, for the average value of NGain in the PMA medium and low categories, the experimental class obtained results of 0.42 and 0.40 higher than the control class namely 0.33 and 0.27 . This can be interpreted that the increase in mathematics learning outcomes in the experimental class is better than the increase in mathematics learning outcomes in the control class. The application of the flipped- 
problem based learning model treatment with the LMS-Google Classroom has an effect on improving the mathematics learning outcomes for each category of student PMA.

Calculation of homogeneity of mathematics learning outcomes data was also carried out using the Kolmogorov-Smirnov Test. The results of testing the homogeneity of the data obtained a significance value greater than 0.05 , which is equal to $0.911>0.05$. So, it can be concluded that the mathematics learning outcomes of students using flipped-problem based learning models with LMSGoogle Classrooms have the same or homogeneous variance. Data on student mathematics learning outcomes were also tested for data normality using the Levene's Test of Quality test. The results of the normality test of students' mathematics learning data obtained a significance value greater than 0.05 which is equal to $0.200>0.05$. Based on the results of the calculation above, it can be concluded that data on the results of mathematics learning outcomes of students are normally distributed.

The NGain data of mathematics learning results are then calculated to see if there is a significant effect after being taught with a flipped-problem based learning model with the LMS-Google Classroom. Based on the results of the homogeneity test data calculation and data normality test, it was obtained that the NGain data of student learning outcomes are homogeneous and normally distributed data, then the next calculation can be done using the Two Path Variance Analysis (ANOVA) test. The results of the calculation of the Two Path ANOVA test can be seen in Table 5 below:

\section{Table 5}

Results of Calculation of Two-way ANOVA

\begin{tabular}{cccccc}
\hline \multicolumn{7}{c}{ Tests of Between-Subjects Effects } \\
\hline \multicolumn{7}{c}{ Dependent Variable: NGain_Mathematics_Score } \\
Source & $\begin{array}{c}\text { Type III Sum of } \\
\text { Squares }\end{array}$ & df & Mean Square & F & Sig. \\
\hline Corrected Model & $.249^{a}$ & 5 & .050 & 6.232 & .000 \\
Intercept & 7.132 & 1 & 7.132 & 893.165 & .000 \\
Learning_Class & .119 & 1 & .119 & 14.946 & .000 \\
PMA & .072 & 2 & .036 & 4.507 & .015 \\
Learning_Class $*$ & .004 & 2 & .002 & .267 & .766 \\
PMA & .447 & 56 & & & \\
Error & 9.740 & 62 & & & \\
Total & .696 & 61 & & & \\
Corrected Total & a. R Squared $=, 358$ (Adjusted R Squared $=, 300)$ \\
\hline
\end{tabular}

Based on Table 5 above, it can be seen that in the learning class factor $F$ value is 14.946 with a significant value of 0.000 . Because the significance value is smaller than $0.05(0,000>0.05)$, it is obtained that $\mathrm{H} 0$ is rejected and $\mathrm{H} 1$ is accepted. So, it can 
be concluded that the mathematics learning outcomes of students taught using the flipped-problem based learning model with the LMS-Google Classroom are higher than the mathematics learning outcomes of students taught using conventional models. To see whether there is an interaction between the PMA values of students and students' mathematics learning outcomes can be seen in Figure 4 below:

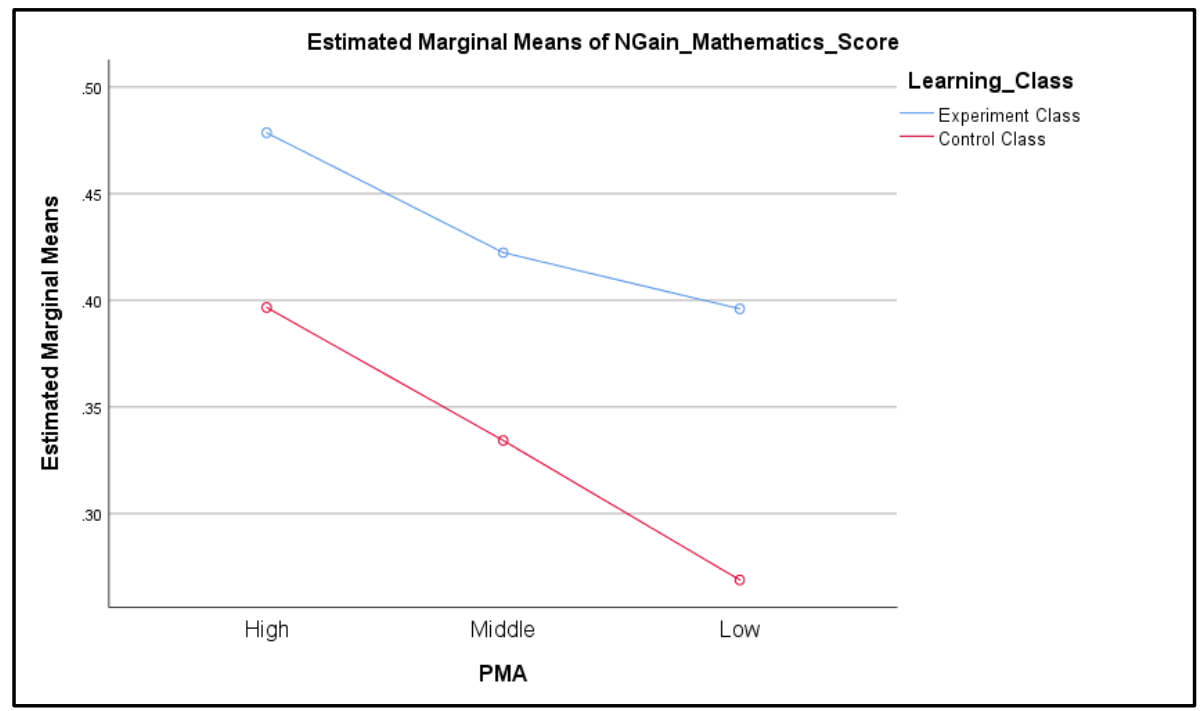

Figure 4

Interaction between Student Mathematics Learning Outcomes and PMA Students

Based on Table 5 above, it can be seen that the learning class and PMA factors obtained $F$ values of 0.267 with a significant value of 0.766 . Because the significant value obtained is greater than $0.05(0,000>0.05)$, it is obtained that $\mathrm{H}_{1}$ is rejected and $\mathrm{H}_{0}$ is accepted. So, it can be concluded that there is no interaction between PMA students and students' mathematics learning outcomes. The graph of the interaction between student learning outcomes with PMA students can also be seen in Figure 4 above. Based on the information given in Figure 3, it can be seen that the graphs of each learning class do not intersect, so that it can be said that the interaction of student learning outcomes with student PMA values does not occur. This proves that the increase in student learning outcomes is purely due to the treatment of flipped-problem based learning models with the LMS-Google Classroom on the learning process. Student PMA values (high, medium, low) do not have a role in giving effect to the improvement of student mathematics learning outcomes. In accordance with the analysis in Table 5 , that $\mathrm{H}_{1}$ is accepted or in other words there is an increase in students' mathematics learning outcomes after being given a flippedproblem based learning model treatment with the LMS-Google Classroom, it is necessary to conduct further analysis of the differences in PMA values of these 
students. Follow-up tests using the Post Hoc-LSD Test, and can be seen in Table 6 below:

\section{Table 6}

Results of Post-Hoc-LSD Advanced Test Calculation

\section{Multiple Comparisons}

Dependent Variable: NGain_Mathematics_Score

LSD

\begin{tabular}{|c|c|c|c|c|c|c|}
\hline \multirow{3}{*}{ (I) PMA } & \multirow{3}{*}{ (J) PMA } & \multirow{3}{*}{ Mean Difference (I-J) } & \multirow{3}{*}{ Std. Error } & \multirow{3}{*}{ Sig. } & \multicolumn{2}{|c|}{$\begin{array}{l}95 \% \text { Confidence } \\
\text { Interval }\end{array}$} \\
\hline & & & & & Lower & Upper \\
\hline & & & & & Bound & Bound \\
\hline \multirow[t]{2}{*}{ High } & Middle & .0536 & .02902 & .070 & -.0045 & .1118 \\
\hline & Low & $.1265^{*}$ & .03442 & .001 & .0575 & .1954 \\
\hline \multirow[t]{2}{*}{ Middle } & High & -.0536 & .02902 & .070 & -.1118 & .0045 \\
\hline & Low & $.0729^{*}$ & .02826 & .013 & .0163 & .1295 \\
\hline \multirow[t]{2}{*}{ Low } & High & $-.1265^{*}$ & .03442 & .001 & -.1954 & -.0575 \\
\hline & Middle & $-.0729^{*}$ & .02826 & .013 & -.1295 & -.0163 \\
\hline $\begin{array}{l}\text { Based on } \\
\text { The erro }\end{array}$ & $\begin{array}{l}\text { bserved } 1 \\
\text { term is } M\end{array}$ & $\begin{array}{l}\text { ans. } \\
\text { in Square (Error) }=, 0\end{array}$ & & & & \\
\hline
\end{tabular}

Based on Table 6 above, the results show that there are differences in the value of increasing learning outcomes (Nain) for each category of student PMA. The results of the Post Hoc-LSD test showed that there were differences in the average increase in learning outcomes between high PMA category students and moderate PMA category students; there is no difference in the average increase in learning outcomes between high PMA category students and low PMA category students; and there is no difference in the average increase in learning outcomes between students in the category of moderate PMA and students in the category of low PMA. So, it can be concluded that the average increase in student learning outcomes with high PMA categories is higher than the average increase in student learning outcomes with moderate or low PMA categories $\left(\mu_{1}>\mu_{2}>\mu_{3}\right)$.

The purpose of this study was to see whether there were effects or influences on the mathematics learning outcomes of second-level high school students after being given treatment with flipped-problem based learning models with the LMS-Google Classroom. Based on the results of the calculation of hypothesis testing using the Two Path ANAVA test, the results showed that groups of students who obtained learning using the flipped-problem based learning model with LMS-Google Classroom had better and more significant improvement in learning outcomes compared to the group of students who obtained learning using conventional learning models. Through the same calculation also obtained results that the 
existence of PMA values of students with high, medium and low categories in the learning process have no role in improving students' mathematics learning outcomes. This shows the fact that the average student mathematics learning outcomes are not influenced by the PMA scores of each student. Increased knowledge of students at the cognitive level is not influenced by the students' initial abilities, but is influenced by the ability of the teacher as a creator to create a fun learning process that can have an impact on improving student learning outcomes themselves (Ernest et al., 2016; Sa'ad, Adamu, \& Sadiq, 2014).

Another factor that gives an increase in high student mathematics learning outcomes is the treatment of flipped-problem based learning given the LMS-Google Classroom. The application of the flipped-problem based learning model with LMSGoogle Classroom is supported by constructivism learning theory that involves students to be active, communicative, imaginative and creative and can collaborate in learning activities. Through the flipped-problem based learning model with the LMS-Google Classroom, students can increase the cognitive level of students in a higher direction, so students are accustomed to thinking analytically to be creative in solving problems. The level of creative cognitive ability in Bloom's taxonomy is the highest level, and is an ability that wants to be developed in the education era 4.0. In addition to constructivism learning theory, the learning theory that supports the application of flipped-problem based learning models with the LMS-Google Classroom is Conversation Theory. Conversation Theory supports constructivism theory that facilitates students in terms of collaboration, communication, interaction, and knowledge construction to have an impact on improving learning outcomes and the quality of learning to be more effective (Ahmed, 2016; Al-Huneidi \& Schreurs, 2012).

In addition to student mathematics learning outcomes, the impact of applying the flipped-problem based learning model with the LMS-Google Classroom also influences the motivation and enthusiasm of students. Learning that combines two different learning environments, namely conventional learning and digital technology-based learning provides new experiences for students. Students feel enthusiastic and happy when media technology is integrated with the learning process, especially mathematics learning, which has been stiff and unattractive. The researcher gave a questionnaire to students taught by using a flipped-problem based learning model with LMS-Google Classroom, which aims to see how far the effects and personal effects of students in learning activities based on flipped classroom. The results of the questionnaire can be seen in Table 7 below: 


\section{Table 7}

Questionnaire Calculation Results Application of Flipped-Problem Based Learning Model Based on LMS-Google Classroom

\begin{tabular}{|c|c|c|c|c|c|c|c|}
\hline No & Type & $\begin{array}{c}\text { SS } \\
\text { Percentage } \\
4\end{array}$ & $\begin{array}{c}\text { S } \\
\text { Percentage } \\
3\end{array}$ & $\begin{array}{c}\text { KS } \\
\text { Percentage } 2\end{array}$ & $\begin{array}{c}\text { TS } \\
\text { Percenta } \\
\text { ge } 1\end{array}$ & $\begin{array}{c}\text { Total } \\
\text { Percentage }\end{array}$ & Result \% \\
\hline 1. & + & $\begin{array}{c}12 \text { org } \\
(36,37 \%)\end{array}$ & $\begin{array}{c}10 \text { org } \\
(30,30 \%)\end{array}$ & $\begin{array}{c}7 \text { org } \\
(21,21 \%)\end{array}$ & $\begin{array}{c}4 \text { org } \\
\left(12,12^{\circ} \%\right)\end{array}$ & 96 & $72,73 \%$ \\
\hline 2. & + & $\begin{array}{c}8 \text { org } \\
(24,25 \%)\end{array}$ & $\begin{array}{c}14 \text { org } \\
(42,42 \%)\end{array}$ & $\begin{array}{c}6 \text { org } \\
(18,18 \%)\end{array}$ & $\begin{array}{c}5 \text { org } \\
(15,15 \%)\end{array}$ & 91 & $68,94 \%$ \\
\hline 3. & - & $\begin{array}{c}6 \text { org } \\
(18,18 \%)\end{array}$ & $\begin{array}{c}5 \text { org } \\
(15,15 \%)\end{array}$ & $\begin{array}{c}8 \text { org } \\
(24,25 \%)\end{array}$ & $\begin{array}{c}14 \text { org } \\
(42,42 \%)\end{array}$ & 69 & $52,27 \%$ \\
\hline 4. & + & $\begin{array}{c}6 \text { org } \\
(18,18 \%)\end{array}$ & $\begin{array}{c}10 \text { org } \\
(30,30 \%)\end{array}$ & $\begin{array}{c}13 \text { org } \\
(39,40 \%)\end{array}$ & $\begin{array}{c}4 \text { org } \\
(12,12 \%)\end{array}$ & 84 & $63,64 \%$ \\
\hline 5. & - & $\begin{array}{c}5 \text { org } \\
(15,15 \%)\end{array}$ & $\begin{array}{c}6 \text { org } \\
(18,18 \%)\end{array}$ & $\begin{array}{c}10 \text { org } \\
(30,30 \%)\end{array}$ & $\begin{array}{c}12 \text { org } \\
(36,37 \%)\end{array}$ & 70 & $53,03 \%$ \\
\hline 6. & - & $\begin{array}{c}4 \text { org } \\
(12,12 \%)\end{array}$ & $\begin{array}{c}7 \text { org } \\
(21,21 \%)\end{array}$ & $\begin{array}{c}8 \text { org } \\
(24,25 \%)\end{array}$ & $\begin{array}{c}14 \text { org } \\
(42,42 \%)\end{array}$ & 67 & $50,76 \%$ \\
\hline 7. & - & $\begin{array}{c}8 \text { org } \\
(24,25 \%)\end{array}$ & $\begin{array}{c}6 \text { org } \\
(18,18 \%)\end{array}$ & $\begin{array}{c}7 \text { org } \\
(21,21 \%)\end{array}$ & $\begin{array}{c}12 \text { org } \\
(36,36 \%)\end{array}$ & 76 & $57,58 \%$ \\
\hline 8. & + & $\begin{array}{c}15 \text { org } \\
(45,46 \%)\end{array}$ & $\begin{array}{c}10 \text { org } \\
(30,30 \%)\end{array}$ & $\begin{array}{c}7 \text { org } \\
(21,21 \%)\end{array}$ & $\begin{array}{c}1 \text { org } \\
(3,03 \%)\end{array}$ & 105 & $79,55 \%$ \\
\hline 9. & + & $\begin{array}{c}16 \text { org } \\
(48,48 \%)\end{array}$ & $\begin{array}{c}12 \text { org } \\
(36,36 \%)\end{array}$ & $\begin{array}{c}5 \text { org } \\
(15,16 \%)\end{array}$ & $\begin{array}{l}0 \text { org } \\
(0 \%)\end{array}$ & 110 & $83,33 \%$ \\
\hline 10. & + & $\begin{array}{c}15 \text { org } \\
(45,46 \%)\end{array}$ & $\begin{array}{c}12 \text { org } \\
(36,36 \%)\end{array}$ & $\begin{array}{c}6 \text { org } \\
(18,18 \%)\end{array}$ & $\begin{array}{l}0 \text { org } \\
(0 \%)\end{array}$ & 108 & $81,82 \%$ \\
\hline 11. & + & $\begin{array}{c}12 \text { org } \\
(36,36 \%)\end{array}$ & $\begin{array}{c}10 \text { org } \\
(30,30 \%)\end{array}$ & $\begin{array}{c}9 \text { org } \\
(27,28 \%)\end{array}$ & $\begin{array}{c}2 \text { org } \\
(6,06 \%)\end{array}$ & 98 & $74,24 \%$ \\
\hline 12. & + & $\begin{array}{c}11 \text { org } \\
(33,33 \%)\end{array}$ & $\begin{array}{c}9 \text { org } \\
(27,27 \%)\end{array}$ & $\begin{array}{c}8 \text { org } \\
(24,25 \%)\end{array}$ & $\begin{array}{c}5 \text { org } \\
(15,15 \%)\end{array}$ & 92 & $69,70 \%$ \\
\hline 13. & - & $\begin{array}{c}4 \text { org } \\
\left(12,12^{\%} \%\right)\end{array}$ & $\begin{array}{c}6 \text { org } \\
(18,18 \%)\end{array}$ & $\begin{array}{c}14 \text { org } \\
(42,42 \%)\end{array}$ & $\begin{array}{c}9 \text { org } \\
(27,28 \%)\end{array}$ & 71 & $53,79 \%$ \\
\hline 14. & - & $\begin{array}{c}5 \text { org } \\
(15,15 \%)\end{array}$ & $\begin{array}{c}4 \text { org } \\
(12,12 \%)\end{array}$ & $\begin{array}{c}8 \text { org } \\
(24,25 \%)\end{array}$ & $\begin{array}{c}16 \text { org } \\
(48,48 \%)\end{array}$ & 64 & $48,48 \%$ \\
\hline 15. & + & $\begin{array}{c}15 \text { org } \\
(45,46 \%)\end{array}$ & $\begin{array}{c}12 \text { org } \\
(36,36 \%)\end{array}$ & $\begin{array}{c}6 \text { org } \\
(18,18 \%)\end{array}$ & $\begin{array}{l}0 \text { org } \\
(0 \%)\end{array}$ & 108 & $81,82 \%$ \\
\hline 16. & + & $\begin{array}{c}19 \text { org } \\
(57,58 \%)\end{array}$ & $\begin{array}{c}14 \text { org } \\
(42,42 \%)\end{array}$ & $\begin{array}{l}0 \text { org } \\
(0 \%)\end{array}$ & $\begin{array}{l}0 \text { org } \\
(0 \%)\end{array}$ & 118 & $89.39 \%$ \\
\hline 17. & + & $\begin{array}{c}18 \text { org } \\
\left(54,55^{\circ}\right)\end{array}$ & $\begin{array}{c}12 \text { org } \\
(36,36 \%)\end{array}$ & $\begin{array}{c}3 \text { org } \\
(9,09 \%)\end{array}$ & $\begin{array}{l}0 \text { org } \\
(0 \%)\end{array}$ & 114 & $86,36 \%$ \\
\hline 18. & - & $\begin{array}{c}3 \text { org } \\
(9,09 \%)\end{array}$ & $\begin{array}{c}5 \text { org } \\
(15,15 \%)\end{array}$ & $\begin{array}{c}15 \text { org } \\
(45,46 \%)\end{array}$ & $\begin{array}{c}10 \text { org } \\
(30,30 \%)\end{array}$ & 67 & $50,76 \%$ \\
\hline 19. & + & $\begin{array}{c}15 \text { org } \\
(45,46 \%)\end{array}$ & $\begin{array}{c}14 \text { org } \\
(42,42 \%)\end{array}$ & $\begin{array}{c}4 \text { org } \\
(12,12 \%)\end{array}$ & $\begin{array}{l}0 \text { org } \\
(0 \%)\end{array}$ & 110 & $83,33 \%$ \\
\hline 20. & - & $\begin{array}{c}3 \text { org } \\
(9,09 \%)\end{array}$ & $\begin{array}{c}2 \text { org } \\
(6,06 \%)\end{array}$ & $\begin{array}{c}12 \text { org } \\
(36,37 \%)\end{array}$ & $\begin{array}{c}16 \text { org } \\
(48,48 \%)\end{array}$ & 58 & $43,94 \%$ \\
\hline Total & & $30,30 \%$ & $27,27 \%$ & $23,64 \%$ & $18,79 \%$ & 1776 & $62,66 \%$ \\
\hline
\end{tabular}

Based on the results of the questionnaire calculation above, it can also be presented in Figure 5 below: 


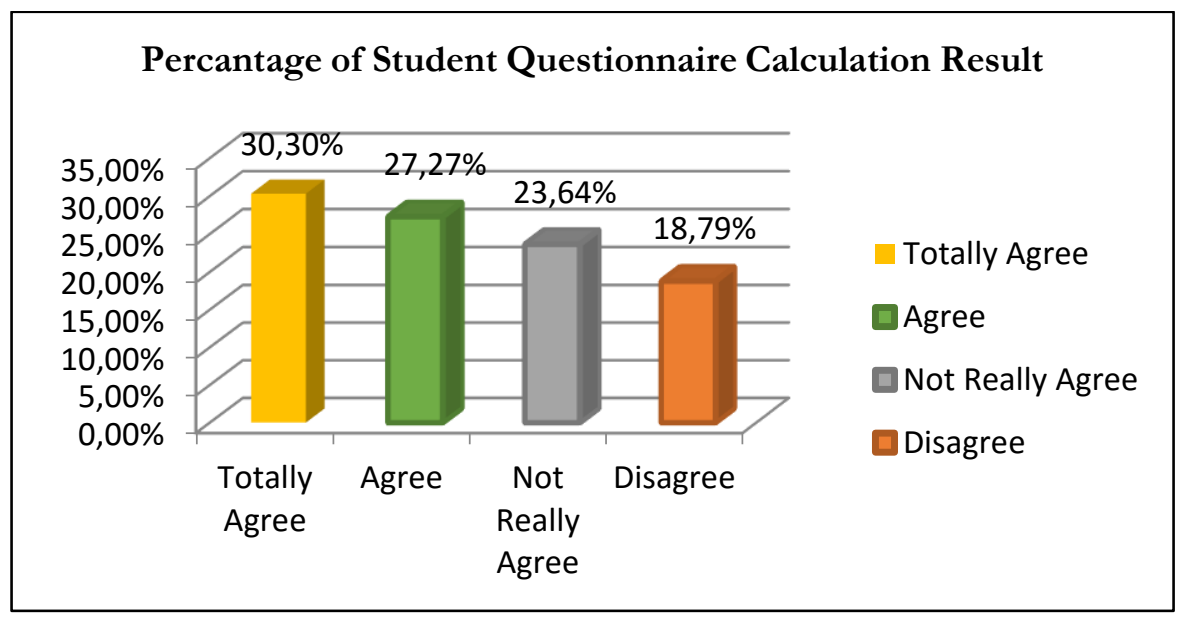

\section{Figure $\mathbf{5}$}

Results of Questionnaire Calculation of Experimental Class Students

The results of the student questionnaire calculation regarding the application of the flipped-problem based learning model with LMS-Google Classroom obtained an average percentage of the questionnaire at the percentage level of $62.66 \%$ and entered in the good category. that the application of the flipped-problem based learning model with LMS-Google Classroom increases students' motivation, enthusiasm and enthusiasm in participating in learning. Through the application of flipped-problem based learning models with LMS-Google Classroom, it provides new experiences for students in participating in Flipped PBL-Google Classroombased learning activities (Muhamad Syazali, 2015).

\section{Conclusion}

From the result of data analysis and calculation performed, the results show that average of learning mathematics outcomes of students in experiment class are higher than students in control class. Based on the result there is no interaction between students' PMA and students learning mathematics outcomes. Learning mathematics using a flipped-problem based learning model with LMS-Google Classroom has a real effect in developing the mathematics learning outcomes of second year high school students in Medan City. Through the flipped-problem based learning model with the LMS-Google Classroom, students can understand the learning process can be done not only in the classroom, but also outside the classroom by using Google Classroom.

In this study, researchers have not fully found a comprehensive explanation of the measurement of the effects of flipped-problem based learning models with LMSGoogle Classroom on student performance in solving real mathematical problems. 
The researcher also feels that further research is needed regarding the application of other types of blended learning models in mathematics learning, as well as the use of other Learning Management Systems (LMS) that are appropriate to the student learning environment. It is likely that there will be more learning factors from internal factors such as motivation, initial ability, gender and from external factors such as economic level, additional education, etc. that affect student performance in solving real problems. Further research needs to be done as an effort to find out and further analyze the contribution of other learning factors that can affect student performance in solving mathematical problems.

\section{Acknowledgements}

The researcher thanked the research partner schools, namely An-Nizam Private High School and Medan 6 Public High School for contributing to this research.

\section{Biodata of the Authors}

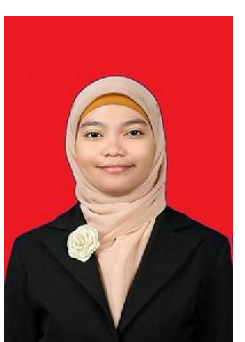

Rahmi Ramadhani was born in Medan, North Sumatera, Indonesia. She holds M.Pd (Magister of Education) in the Mathematics Education from State University of Medan in 2015. She is a lecturer in the Computer Engineering Department, Faculty of Engineering and Computer Science, Universitas Potensi Utama, Medan, North Sumatera, Indonesia. Her research focuses on mathematics education, Problem-Based Learning, Blended Learning, ICT in teaching and learning, problem solving ability, STEM education and ethno-mathematics.

Affiliation: Faculty of Engineering and Computer Science, Universitas Potensi Utama, Indonesia.

E-mail: rahmiramadhani3@gmail.com

ORCID number: orcid.org/0000-0002-8049-7234

Phone: (+62)81262900365 


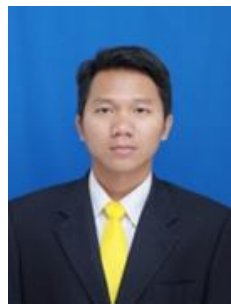

Rofiqul Umam was born in Bandar Lampung City, Indonesia. He holds M.Sc (Master of Science) in the Physics Department, Gadjah Mada University, Indonesia in 2016. Currently, he is a $\mathrm{PhD}$ student in School of Scienceand Technology, at Kwansei Gakuin University, Japan. His research focuses on Science education, material physics, theoretical physics, and geophysics. Affiliation: School of Science and Technology, Kwansei Gakuin University, Sanda-Shi, Hyogo-Ken, Japan.

E-mail: egk71822@,kwansei.ac.jp

ORCID number: orcid.org/0000-0002-7095-5967

Phone: (+81)8087288103

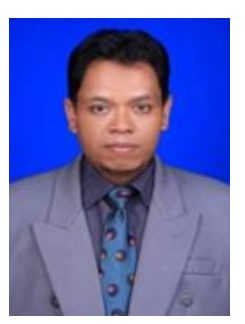

Abdurrahman was born in Rangkasbitung, Indonesia. He completed his high school education at The First Rangkasbitung Public High School in 1988. He graduated from Department of Science Education, Graduate School of Indonesia University of Education in 2010. He is an assistant professor, Department of Mathematics and Science Education, Faculty of Teacher Training and Education, Lampung Province, Indonesia. His research focuses on science teacher education, science teaching and learning, STEM education and literacy, problem-based learning, project-based learning, and multimodal representations in science learning. Affiliation: Department of Science Education, Faculty of Teacher Training and Education, University of Lampung, Bandar Lampung, Lampung Province, Indonesia.

E-mail: abdurrahman.1968@,fkip.unila.ac.id.

ORCID number: orcid.org/0000-0003-4289-6557

Phone: (+62)8127911494

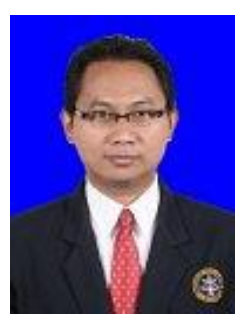

Muhamad Syazali was born in Lampung, Indonesia. He holdsM.Si (Magister of Science) in the Applied Mathematics Department from Institut Pertanian Bogor, Indonesia in 2011. $\mathrm{He}$ is a lecturer in the Mathematics Education Department, Faculty of Education and Teacher Training, Universitas Islam Negeri RadenIntan, Lampung, Indonesia. His research focuses on mathematics education, Applied Mathematics, Modeling Mathematics, and Operation Research.

Affiliation: Mathematics Education Department, Faculty of Education and Teacher Training, Universitas Islam Negeri Raden Intan, Lampung, Indonesia.

E-mail:muhamadsyazali@,radenintan.ac.id

ORCID number: orcid.org/0000-0003-2907-0363

Phone:(+62)8984369924 


\section{References}

Abdurrahman, Cris Ayu Setiyaningsih, T. J. (2019). Implementating Multiple Representation-Based Worksheet to Develop Critical Thinking Skills. Journal of Turkish Science Education, 16(1), 138-155. https:/ / doi.org/10.12973/tused.10271a Abdurrahman, Saregar, A., \& Umam, R. (2018). The Effect of Feedback as soft scaffolding on onggoing assessment toward the quantum physics concept mastery of the prospective physics teachers. Jurnal Pendidikan IP A Indonesia, 7(1), 34-40. https://doi.org/10.15294/jpii.v6i2.7239

Abdurrahman, A., Nurulsari, N., Maulina, H., \& Ariyani, F. (2019). Design and Validation of Inquiry-based STEM Learning Strategy as a Powerful Alternative Solution to Facilitate Gifted Students Facing 21st Century Challenging To cite this article: Journal for the Education of Gifted Young, 7(March), 33-56. https://doi.org/10.17478/jegys.513308

Abid Azhar, K., \& Iqbal, N. (2018). Effectiveness of Google Classroom: Teachers' Perceptions. Prizen Social Sciemce Journal, 2(2). Retrieved from https://www.researchgate.net/publication/327417783

Ahmed, H. O. . (2016). Flipped Learning As A New Educational Paradigm: An Analytical Critical Study. European Scientific Journal, 12(10), 417-444. https://doi.org/doi: 10.19044/esj.2016.v12n10p417

Akkoyunlu, B., \& Soylu, M. Y. (2008). A Study of Student's Perceptions in a Blended Learning Environment Based on Different Learning Styles. Educational Technology \& Society, 11(1), 183-193.

Al-Huneidi, A. M., \& Schreurs, J. (2012). Constructivism Based Blended Learning in Higher Education. IJET, 4-9. https://doi.org/http://dx.doi.org/10.3991/ijet.v7i1.1792

Andrade, M., \& Coutinho, C. (2016). Implementing Flipped Classroom in Blended Learning environments: a Proposal Based on the Cognitive Flexibility Theory. ELearn , 1115-1125. from https://core.ac.uk/download/pdf/76177074.pdf

Borba, M. C., Askar, P., Engelbrecht, J., Gadanidis, G., Llinares, S., \& Aguilar, M. S. (2016). Blended learning, e-learning and mobile learning in mathematics education. ZDM, 48(5), 589-610. https://doi.org/10.1007/s11858-016-0798-4

Capone, R., De Caterina, P., \& Mazza, G. (2017). Blended Learning, Flipped Classroom, and Virtual Environment: Challenges and Opportunities for The $21 \mathrm{st}$ Century Students. Proceedings of EDULEARN17 Conference, 10478-10482. Barcelona, Spain.

Çevikbaş, M., \& Argün, Z. (2017). An Innovative Learning Model in Digital Age: Flipped Classroom. Journal of Education and Training Studies, 5(11). https://doi.org/10.11114/jets.v5i11.2322

Chin, C., Munip, H., Miyadera, R., Thoe, N., Ch'ng, Y., \& Promsing, N. (2018). Promoting Education for Sustainable Development in Teacher Education integrating Blended Learning and Digital Tools: An Evaluation with Exemplary Cases. Eurasia Journal of Mathematics, Science and Technology Education, 15(1). https://doi.org/10.29333/ejmste/99513

D’addato, T., \& Miller, L. R. (2016). An Inquiry Into Flipped Learning in Fourth 
Grade Math Instruction. Canadian Journal of Action Research, 17(2), 33-35.

Dočekal, V., \& Tulinská, H. (2015). ScienceDirect The impact of technology on education theory. Procedia-Social and Behavioral Sciences, 174, 3765-3771. https://doi.org/10.1016/j.sbspro.2015.01.1111

Eady, M. J., \& Lockyer, L. (2013). Tools for learning: technology and teaching strategies. In Teach in the Primary School. Retrieved from http://ro.uow.edu.au/asdpapers/403

Ernest, P., Skovsmose, O., van Bendegem, J. P., Bicudo, M., Miarka, R., Kvasz, L., \& Moeller, R. (2016). The Philosophy of Mathematics Education. (July). https://doi.org/10.1007/978-3-319-40569-8

Ghavifekr, S., \& Rosdy, W. A. W. (2015). Teaching and learning with technology: Effectiveness of ICT integration in schools. International Journal of Research in Education and Science (IJRES), 1(2), 175-191. Retrieved from www.ijres.net

Gladys Ann O. Malto, Dalida, C. S., \& Lagunzad, C. G. B. (2018). Flipped Classroom Approach in Teaching Biology: Assessing Students' Academic Achievement and Attitude Towards Biology. 4th International Research Conference on Higher Education, 540-544. https://doi.org/10.18502/kss.v3i6.2403

Hake, R. . (1999). Analyzing Change/Gain Score. Retrieved from http://www.physics.indiana.edu/sdi.AnalyzingChange-Gain.pdf

Harahap, F., \& Manurung, B. (2019). The Effect of Blended Learning on Student's Learning Achievement and Science Process Skills in Plant Tissue Culture Course. International Journal of Instruction, 12(1), 521. https://doi.org/10.29333/iji.2019.12134a

Heidari, R., \& Rajabi, F. (2017). An Investigation of the Relationship between Mathematics Performance of Students in a Non-Routine Problem, according to Grade and Gender. International Journal of Innovation in Science and Mathematics Education, 25(3), 11-19.

Hu, Y. H., Xing, J., \& Tu, L. P. (2018). The effect of a problem-oriented teaching method on university mathematics learning. Eurasia Journal of Mathematics, Science and Technology Education. https://doi.org/10.29333/EJMSTE/85108

Larsen, J. (2015). Adult Students' Experiences of a Flipped Mathematics Classroom. Adults Learning Mathematics: An International Journal, 10(1), 50-67. Retrieved from https:// files.eric.ed.gov/fulltext/EJ1077724.pdf

Lavicza, Z. (2010). Integrating technology into mathematics teaching at the university level. ZDM, 42(1), 105-119. https://doi.org/10.1007/s11858-0090225-1

Lefa, B. (2014). The Piaget Theory of Cognitive Development: An Educational. (September). Lestari, F., Saryantono, B., Syazali, M., Saregar, A., Madiyo, M., Jauhariyah, D., \& Umam, R. (2019). Cooperative Learning Application with the Method of "Network Tree Concept Map": Based on Japanese Learning System Approach. Journal for the Education of Gifted Young Scientists, 7(1), 15-32. Retrieved from http://dergipark.gov.tr/jegys/issue/44329/471466

Loch, B., Borland, R., \& Sukhorukova, N. (2016). How to engage students in blended learning in a mathematics course: The students' views. Retrieved from http://2016conference.ascilite.org/wp- 
content/uploads/ascilite2016_loch_concise.pdf

Lopes, A. P., \& Soares, F. (2018). Flipping A Mathematics Course, A Blended Learning Approach. Proceedings of INTED2018 Conference, 3844-3853. Retrieved from http://recipp.ipp.pt/bitstream/10400.22/12042/1/03_Flipping a Mathematics Course $\% 2 \mathrm{C}$ a blended learning approach.pdf

Maskur, R., Syazali, M., \& Utami, L. F. (2019). Islamic-Nuanced Calculus Module with Open-Ended Approach in Real Number System Material. Journal of Physics: Conference Series, 1155(1). https:/ / doi.org/10.1088/1742-6596/1155/1/012081

Maya, R., \& Sumarmo, U. (2011). Mathematical Understanding and Proving Abilities: Experiment With Undergraduate Student By Using Modified Moore Learning Approach. Journal on Mathematics Education, 2(2), 231-250.

Murati, R., \& Ceka, A. (2017). The Use of Technology in Educational Teaching. Journal of Education and Practice, 8(6).

O'flaherty, J., \& Phillips, C. (2015). The use of flipped classrooms in higher education: A scoping review 2 . The Internet and Higher Education, 25, 85-95. https://doi.org/10.1016/j.iheduc.2015.02.002

Ozdamli, F., \& Asiksoy, G. (2016). Flipped classroom approach. World Journal on Educational Technology: Current Issues, 8(2), 98-105.

Ramadhani, R., \& Narpila, S. D. (2018). Problem based learning method with geogebra in mathematical learning. International Journal of Engineering and Technology (UAE), 7(3.2 Special Issue 2).

Rohman, F. (2017). Google Classroom: Jadikan Kelas Digital di Genggaman Anda. Bojonegoro: Pustaka Intermedia.

Rufaidah, E., AtIrsyadi, K. A., Saregar, A., \& Umam, R. (2018). The Effect of HALAL Label to Increase Domestic and International Tourism : Case Study In Lombok, Indonesia. International Journal of Management and Business Research, 8(4), 29-36.

Sa'ad, T. U., Adamu, A., \& Sadiq, A. M. (2014). The Causes of Poor Performance in Mathematics among Public Senior Secondary School Students in Azare Metropolis of Bauchi State, Nigeria. IOSR Journal of Research \& Method in Education (IOSR-JRME), 4(6), 32-40. Retrieved from www.iosrjournals.org

Salkind, N. . (2007). Encyclopedia of Measurement and Statistica Volume 2. United States of America: SAGE Publications, Inc.

Scholarsarchive, B., \& Young, L. L. (2014). Online Student Discussions in a Blended Learning Classroom: Reconciling Conflicts Between a Flipped Instruction Model and ReformBased Mathematics (Brigham Young University). Retrieved from https://scholarsarchive.byu.edu/etd/4209

Shah, S. A. (2013). ScienceDirect Making the Teacher Relevant and Effective in a Technology-Led Teaching and Learning Environment. Procedia-Social and Behavioral Sciences, 103, 612-620. https://doi.org/10.1016/j.sbspro.2013.10.379

Staker, H., \& Horn, M. B. (2012). Classifying K-12 Blended learning. Retrieved from https://www.christenseninstitute.org/wpcontent/uploads/2013/04/Classifying-K-12-blended-learning.pdf

Strohmyer, D. (2016). Student Perceptions of Flipped Learning in a High School Math 
Classroom (Walden University). Retrieved from http://scholarworks.waldenu.edu/dissertations

Syahrir, S., Syazali, M., Maskur, R., Amrulloh, M. A., Sada, H. J., \& Listiani, B. (2019).

Calculus Module for Derivative Application Materials with an Islamic Contextual Teaching and Learning Approach. Journal of Physics: Conference Series, 1155(1). https://doi.org/10.1088/1742-6596/1155/1/012079

Syazali, M. (2015). Pengaruh Model Pembelajaran Creative Problem Solving

Berbantuan Maple II Terhadap Kemampuan Pemecahan Masalah Matematis. AlJabar: Jurnal Pendidikan Matematika, 6(1), 91-98. https://doi.org/https://doi.org/10.24042/ajpm.v6i1.58

Syazali, M., Putra, F. G., Rinaldi, A., Utami, L. F., Widayanti, Jermsittiparsert, K., \&

Umam, R. (2019). Partial correlation analysis using multiple linear regression:

Impact on business environment of digital marketing interest in the era of industrial revolution 4.0. Management Science Letters, 9.

Syazali, M., Sari, N. R., Sukawati, S., Sari, W. R., Pertiwi, S. D., Putra, A., \& Putra, F.

G. (2019). Islamic-Nuanced Linear Algebra Module with Problem-Based Learning Approach for Linear Equation System Material. Journal of Physics: Conference Series, 1155(1). https://doi.org/10.1088/1742-6596/1155/1/012097

Torii, C. V., \& Carmen, A. (2013). The Impact of Educational Technology on the Learning Styles of Students. Procedia-Social and Behavioral Sciences, 83, 851-855.

Tsai, T., Lin, J., \& Lin, L. (2017). A Flip Blended Learning Approach for ePUB3 eBook-based Course Design and Implementation. Eurasia Journal of Mathematics, Science and Technology Education, 14(1), 123-144. https://doi.org/10.12973/ejmste/79629 